\title{
Severe modifications in source-sink ratio influence the susceptibility of bananas to crown rot and its phenolics content
}

\author{
Cecile A. Ewané ${ }^{1,2,3}$ (D) | Katherine Nott ${ }^{4,5}$ | Ludivine Lassois ${ }^{1,6}$ | Philippe Lepoivre ${ }^{1}$ | \\ Luc de Lapeyre de Bellaire $2,7,8$
}

${ }^{1}$ Gembloux Agro-Bio Tech, Plant Pathology Unit, University of Liege, Gembloux, Belgium ${ }^{2}$ CARBAP, Centre Africain de Recherches sur Bananiers et Plantains, Unité de Phytopathologie, Douala, Cameroon ${ }^{3}$ Department of Biochemistry, Faculty of Science, University of Yaoundé 1, Yaoundé, Cameroon

${ }^{4}$ Gembloux Agro-Bio Tech, Analytic Chemistry Unit, University of Liege, Gembloux, Belgium

${ }^{5}$ Gembloux Agro-Bio Tech, General and Organic Chemistry Unit, University of Liege, Gembloux, Belgium

${ }^{6}$ Gembloux Agro-Bio Tech, Plant Genetics Laboratory, TERRA Research Centre, University of Liege, Gembloux, Belgium ${ }^{7}$ CIRAD, UPR GECO, Montpellier, France ${ }^{8} \mathrm{GECO}$, Université de Montpellier, CIRAD, Montpellier, France

\section{Correspondence}

Cecile A. Ewané, Department of Biochemistry, Faculty of Science, University of Yaoundé 1, Yaoundé, Cameroon. Email: cecile-annie.ewane@facsciences-uy1.cm

\begin{abstract}
Banana susceptibility to crown rot is influenced by many biotic and abiotic preharvest factors, which include source-sink (So-Si) ratio modifications through trimming of leaves and fruit. Banana plant's resistance to biotic stress has been previously correlated to its phenolic content; it is hypothesized that the crown's phenolic content may influence the fruit's susceptibility. The aim of this work was to investigate the influence of severe So-Si ratio modifications, via the removal of leaves and fruit, and the involvement of phenolics in the fruit's susceptibility to crown rot. Fruit susceptibility was evaluated 13 days postinoculation (13 dpi) with Colletotrichum musae. Banana crowns obtained on the day of harvest before inoculation (dhbi) and $13 \mathrm{dpi}$ were analysed for changes in phenolics using GC-MS, HPLC, and LC-MS devices. Severe So-Si ratio modifications had a significant effect $(p<.001)$ on susceptibility, fruits of low So-Si ratio being most susceptible. It also significantly influenced $(p<.001)$ some tree and fruit characteristics. The less susceptible (S-) crowns had higher amounts of phenolics compared to the more susceptible $(\mathrm{S}+)$ ones. Catecholamines were identified as the major phenolics in banana crown, notably dopamine compared to norepinephrine and normetanephrine. Hydroxycinnamic acids (ferulic acid and its derivatives) were significantly accumulated $(p<.001)$ the dhbi in S-crowns compared to $\mathrm{S}+$ crowns, but decreased $13 \mathrm{dpi}$. Phenolics have a possible role in the biochemical defence of banana crown and could be used by producers as a chemical criterion for estimation of the level of banana's susceptibility to crown rot.
\end{abstract}

\section{KEYWORDS}

chromatographic methods (GC-MS, HPLC, LC-MS), crown rot, fruit susceptibility, Musa spp., phenolic, source-sink ratio modifications

\section{1 | INTRODUCTION}

Crown rot is a postharvest disease of bananas affecting the tissue uniting fruit peduncles. Caused by a broad, unspecific parasitic complex, it is the most important postharvest disease affecting the quality of exported bananas. Within this complex, Colletotrichum musae is the most commonly described pathogenic species (Finlay and Brown, 1993; Krauss and Johanson, 2000; Lassois et al., 2010a;
Nuratika et al., 2018). The disease develops during shipping, ripening, commercialization, and storage and has a negative impact on the market value of the bananas (Slabaugh and Grove, 1982). Crown rot control relies mainly on the application of postharvest fungicides (Slabaugh and Grove, 1982; de Lapeyre de Bellaire and Nolin, 1994). Nevertheless, seasonal and spatial variations in the performance of chemical control have been observed. It has been suggested that these spatiotemporal fluctuations may represent variations in 
the quality potential of the fruit, which is influenced by preharvest factors such as agronomic practices and agroecological conditions (Chillet and de Lapeyre de Bellaire, 1996; Lassois et al., 2010a).

Fruit susceptibility to crown rot disease is an important component of this quality potential (Lassois et al., 2010a) and a specific methodology has been designed for its evaluation (de Lapeyre de Bellaire et al., 2008). More recently it has been shown that source-sink (So-Si) ratio modifications, through trimming of leaves and fruit, significantly influenced the susceptibility to crown rot disease of bananas (Lassois et al., 2010b). Therefore, using such So-Si ratio modifications is an ideal model to obtain fruits with contrasting susceptibility levels in order to understand underlying mechanisms of this plant-pathogen interaction. In previous work using cDNA-AFLP, Lassois et al. (2011) identified some genes involved in the susceptibility of bananas to crown rot disease in fruits exhibiting such contrasting disease responses. The results highlighted that metabolic pathways are potentially involved in this plant-pathogen interaction and particularly suggested that phenolics, notably dopamine, could be involved in the quantitative response of bananas to crown rot.

Dopamine and products that derive from its oxidation are the main phenolic compounds in bananas and these compounds have a fungitoxic activity against C. musae (Muirhead and Deverall, 1984), and antioxidant properties (Kanazawa and Sakakibara, 2000; Someya et al., 2002). Besides the high concentration of phenols, phenylalanine ammonia-lyase and oxidative enzymes like peroxidase and polyphenol oxidase (PPO) were reported in many resistant banana tissues such as in the interaction between Musa spp. and Fusarium oxysporum f. sp. cubense (cause of Panama disease) (Kavino et al., 2009). Amongst the many diverse secondary metabolites involved in banana's resistance to different pathogens, preformed and induced phenolic compounds have been widely reported in the literature as potential participants in the banana tree defence mechanisms (Ewané et al., 2012a).

Phenolics were shown to be involved in the preformed defence mechanism of the banana tree against black leaf streak disease, via specialized cells of the mesophyll that store phenolics in partially resistant cultivar tissues (Beveraggi et al., 1995; El Hadrami, 1997). Phenolics were also involved in induced defence mechanisms. For example, after a wound or an inoculation with C. musae, several phytoalexins (phenylphenalenones, irenolone, and emenolone types) were induced in the tissues of green bananas (Luis et al., 1993; Kamo et al., 1998, 2001). Higher contents of several phenolic compounds have been observed in roots tissues of banana cultivars resistant to phytophagous nematodes and the role of these phenolics in defence mechanisms has been reported (Valette et al., 1998; Collingborn et al., 2000; de Ascensao and Dubery, 2003; Wuyts et al., 2007). Despite convergent information on plant defence mechanisms involving phenolics in bananas, the fruit susceptibility to crown rot disease has not yet been linked to fluctuations in phenolic contents of the tissues of the banana crown.

The objective of this work was to understand better the role of phenolics in the susceptibility of bananas to crown rot disease. For this, we have first characterized the effect of a very broad range of So-Si ratio modifications on variations of susceptibility to crown rot disease. The objective was to select the most extreme situation for both susceptible ( $\left.\mathrm{S}_{+}\right)$and less susceptible (S-) fruits, exploring a broader range of So-Si ratios than former studies (Lassois et al., 2010a, 2010b, 2011). In a second step, preformed (preinoculation) and induced (postinoculation) phenolics were analysed in the crowns of both extreme situations (S+ and S-) using HPLC and LC-MS in order to identify phenolic compounds associated with a lower susceptibility to crown rot disease. Catecholamines, which might also play a specific role in plant defence mechanisms in bananas, were also studied through GC-MS analysis (Szopa et al., 2001).

\section{MATERIALS AND METHODS}

\section{1 | Plant material}

Banana fruits were harvested from banana plants (Musa acuminata [AAA group, Cavendish subgroup] 'Grande Naine'), grown on a commercial banana farm belonging to the PHP (Plantations du Haut Penja) banana company, in the Littoral Region of Cameroon (Bouba, $100 \mathrm{~m}$ ). The average temperature of the locality is $27^{\circ} \mathrm{C}$ and the mean annual rainfall is $2,500 \mathrm{~mm}$. The banana plants were selected at flowering (horizontal finger stage) and their bunches covered with a plastic sleeve. Each bunch was tied with a belt, coloured to indicate the time for harvest, which was carried out at a constant physiological age when the sum of the daily mean temperature accumulated by the fruit at the $14^{\circ} \mathrm{C}$ threshold, between flowering and harvest, reached 900 degree days (dd) (Jullien et al., 2008). Therefore, temperatures were recorded on the experimental plot via an electronic probe (Tinytag Plus; Gemini Data Loggers) with regular data capture (every $15 \mathrm{~min}$ ) and the calculation of an average daily temperature from all the daily data.

\section{2 | Experimental design for source-sink ratio modifications}

Various So-Si ratio modifications were performed at the flowering stage (fingers on horizontal position) by removing sources (leaves, L) and sinks (hands of the bunch, $\mathrm{H}$, a hand being a cluster of fruits). The five following So-Si ratios were performed at that stage:

12L/1H: 12 leaves and 1 hand remaining, source-sink ratio = 8

12L/2H: 12 leaves and 2 hands remaining, source-sink ratio $=4$

12L/8H: 12 leaves and 8 hands remaining, source-sink ratio $=1$ (reference)

2L/8H: 2 leaves and 8 hands remaining, source-sink ratio $=0.17$ $1 \mathrm{~L} / 8 \mathrm{H}: 1$ leaf and 8 hands remaining, source-sink ratio $=0.08$

The values of the So-Si ratio were calculated as described by Lassois et al. (2010b), taking 12 leaves/8 hands as the reference for a banana tree where no leaves or hands were removed.

Five banana trees at the same flowering stage were selected for each treatment. This selection was repeated three times for three 
successive weeks. At harvest, for each harvested banana tree, two clusters consisting of four banana fruits were cut off from the second hand (except for the treatment 12L/1H). The first cluster was used for identification of preformed phenolic compounds on the day of harvest before inoculation (dhbi); the banana crown was immediately frozen in liquid nitrogen and freeze-dried after removal of the green parts for further biochemical analyses. The second cluster was used for artificial inoculations and evaluation of susceptibility to crown rot at 13 days postinoculation (13 dpi). At this time, crowns were also frozen in liquid nitrogen, and freeze-dried after removal of the green and necrotic parts (Figure 1) for identification of induced phenolic compounds.

The grade (i.e., fruit diameter) and length of the same medial fruit harvested on the second hand as well as the number of leaves remaining at harvest (NLH) were also assessed for each sampled banana plant.

\subsection{Evaluation of susceptibility to crown rot disease}

The susceptibility of bananas to crown rot was evaluated through the artificial inoculation of banana clusters with a single spore isolate of C. musae (de Lapeyre de Bellaire et al., 2008). Bunches were harvested on the day of experimentation and their second hands were transported to the laboratory. The medial part of the hand was cut into two clusters of four banana fingers. The cuttings were squared, with regular and clear-cut sections in order to obtain similar crowns between the clusters. Once latex ran out, crown tissues were dried with absorbent paper and sterilized by dipping them into $50 \%$ alcohol. Fruits were then laid out at room temperature for $2 \mathrm{hr}$ to allow the crowns to dry. A droplet of $50 \mu \mathrm{l}$ of a C. musae suspension $\left(10^{4}\right.$ conidia $\left./ \mathrm{ml}\right)$ was then deposited at the top of the crown. A sterilized square filter paper of $1 \mathrm{~cm}^{2}$ was placed on the droplet in order to keep the inoculum in place. Three hours after inoculation, the clusters were packed in perforated plastic bags in commercial boxes and stored under stable conditions at $13^{\circ} \mathrm{C}$ for 13 days (Ewané et al., 2012b). At the end of this storage period, an evaluation of the internal progression of the rot within the crown was carried out. The clusters were divided into two parts and the transverse cutting of the crown allowed a visualization of the spread of rot into the crown. The internal necrotic surface (INS) expressed in $\mathrm{mm}^{2}$ was calculated by assuming a rectangular shape to the internal necrosis. Its value was taken as a measure of the fruit's susceptibility to crown rot.

\begin{tabular}{|c|c|c|c|c|c|c|c|c|c|}
\hline \multirow{2}{*}{$\begin{array}{l}\text { Replicate } \\
\text { Modalities }\end{array}$} & \multicolumn{7}{|c|}{ First (1) harvest week (HW) } & \multirow{2}{*}{$\begin{array}{l}2 \text { (HW) } \\
\text { Same }\end{array}$} & \multirow{2}{*}{$\begin{array}{l}3 \text { (HW) } \\
\text { Same }\end{array}$} \\
\hline & \multicolumn{2}{|r|}{$12 \mathrm{~L} / 1 \mathrm{H}$} & $12 \mathrm{~L} / 2 \mathrm{H}$ & $12 \mathrm{~L} / 8 \mathrm{H}$ & $2 \mathrm{~L} / 8 \mathrm{H}$ & \multicolumn{2}{|c|}{$1 \mathrm{~L} / 8 \mathrm{H}$} & & \\
\hline Banana trees & \multicolumn{2}{|r|}{5} & 5 & 5 & 5 & \multicolumn{2}{|c|}{5} & 1 & 1 \\
\hline $\begin{array}{l}\text { Characteristics } \\
\text { measured at harvest (900 dd) }\end{array}$ & \multicolumn{2}{|c|}{$\begin{array}{l}\text { - Number of Leaves at } 900 \mathrm{dd} \\
\text {-Fruit Grade at } 900 \mathrm{dd} \\
\text {-Fruit Length at } 900 \mathrm{dd}\end{array}$} & & & & & & & \\
\hline Bunches & \multicolumn{2}{|r|}{$2^{\text {nd }}$ hand } & & & $i$ & & & & \\
\hline Hands & \multicolumn{2}{|c|}{2 Clusters of 4 Fingers } & 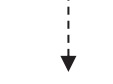 & 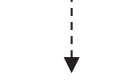 & 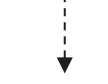 & \multicolumn{2}{|c|}{$\downarrow$} & & \\
\hline Clusters (Stage) & dhbi & 13dpi & Same & Same & Same & \multicolumn{2}{|c|}{ Same } & & \\
\hline Crowns & Freeze-dried & $\begin{array}{l}\text { - Inoculation } \\
\text { - Kept } 13^{\circ} \mathrm{C} \text { for } 13 \text { days } \\
\text { - INS Assessment } \\
\text { - Freeze-dried }\end{array}$ & Same & Same & Same & \multicolumn{2}{|c|}{ Same } & Same & Same \\
\hline $\begin{array}{l}\text { Samples selected for } \\
\text { biochemical analyses }\end{array}$ & $\begin{array}{l}\text { Freeze-dried } \\
\text { dhbi crowns }\end{array}$ & $\begin{array}{l}\text { Freeze-dried } \\
\text { 13dpi crowns }\end{array}$ & Not used & Not used & Not used & $\begin{array}{l}\text { Freeze-dried } \\
\text { dhbi crowns }\end{array}$ & $\begin{array}{l}\text { Freeze-dried } \\
\text { 13dpi crowns }\end{array}$ & Same & Same \\
\hline Replicate & $\begin{array}{l}3 \text { Sar } \\
\text { Less }\end{array}$ & $\begin{array}{l}\text { nples for each } \\
\text { susceptible (S+) }\end{array}$ & - & - & - & $\begin{array}{l}3 \text { Sampl } \\
\text { More sus }\end{array}$ & $\begin{array}{l}\text { for each } \\
\text { eptible (S-) }\end{array}$ & & \\
\hline Analyses done & & & None fol & this week & & & & $\begin{array}{l}\text { HPLC } \\
\text { LC-MS }\end{array}$ & GC-MS \\
\hline
\end{tabular}

FIGURE 1 Experimental design for the study of the effect of source-sink ratio modifications on the susceptibility of bananas to crown rot disease. L, leaves; H, hand or cluster of fruits; dhbi, day of harvest before inoculation; dpi, days postinoculation; INS, internal necrotic surface 
2.4 Analysis of phenolic compounds of banana crowns

Two different extraction methods were needed for these analyses, because banana crown tissues might contain free soluble (or lightly bound to cell wall) phenolic compounds (catecholamine and soluble phenolics) and compounds bound to the cell walls (bound phenolics).
These methods are described below. The free soluble phenolic fraction was analysed by HPLC + LC-MS. However, a more specific analysis was required for catecholamine as it coelutes with ascorbic acid (added as a protective in the solvent), as previously reported by Wuyts et al. (2007). Therefore, catecholamines were analysed by GC-MS. The bound phenolics were analysed by HPLC + LC-MS (Figure 2).

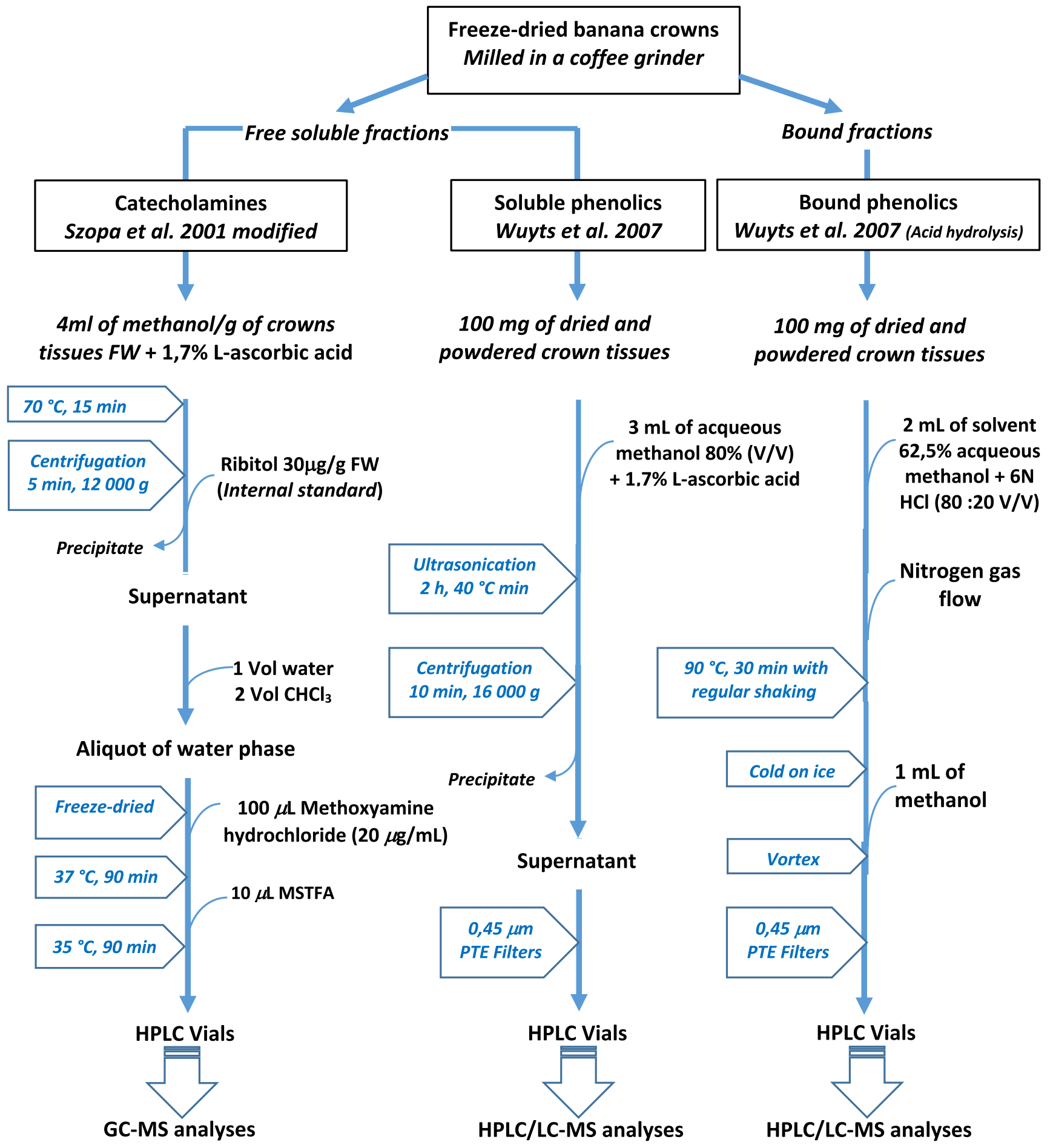

FIGURE 2 Methods of extraction and analysis of catecholamines and phenolics (soluble and bound) from freeze-dried banana crowns 


\subsection{1 | Sample preparation}

Crowns for analysis were selected from two So-Si ratio treatments that led to high and low susceptibility: S+ (high susceptibility, treatment $1 \mathrm{~L} / 8 \mathrm{H}$, So-Si $=0.08$ ) and $\mathrm{S}$ - (low susceptibility, treatment $12 \mathrm{~L} / 1 \mathrm{H}$, So-Si = 8; Figure 1). The crowns were collected at two stages: the day of harvest before inoculation ( $\mathrm{S}+/ \mathrm{dhbi}$ and $\mathrm{S}-/ \mathrm{dhbi})$ and at $13 \mathrm{dpi}(\mathrm{S}+/ 13 \mathrm{dpi}$ and $\mathrm{S}-/ 13 \mathrm{dpi})$. Only crowns of the same field replicate were compared. For GC-MS analysis, three $\mathrm{S}+$ and three S- banana crowns harvested on bunches from the third replicate were selected and for HPLC and LC-MS analyses, three S+ and three S- crowns harvested on bunches from the second replicate were selected. Prior to the analyses, the freeze-dried crowns were milled in a coffee grinder.

\subsection{2 | Methanolic extraction of phenolic compounds}

\section{Extraction of free soluble fraction}

For the soluble phenolics, $100 \mathrm{mg}$ of dried and powdered crown tissues were placed in a Pyrex tube with a Teflon-coated cover and extracted with $3 \mathrm{ml}$ aqueous methanol 80\% (vol/vol) containing 1.7\% L-ascorbic acid (wt/vol). The mixture was ultrasonicated for $2 \mathrm{hr}$ at $40^{\circ} \mathrm{C}$ and centrifuged at $16,000 \times \mathrm{g}$ for $10 \mathrm{~min}$. The supernatant was passed through $0.45 \mu \mathrm{m}$ filters into HPLC vials.

Catecholamine extractions were carried out similarly, but, according to the method reported by Szopa et al. (2001), modified by the addition of L-ascorbic acid (1.7\% wt/vol) to the extraction solvent as an antioxidant (Figure 2).

\section{Extraction of bound fraction}

Bound phenolic compounds were extracted by acid hydrolysis following the method used by Wuyts et al. (2007). Dried and milled crown tissue $(100 \mathrm{mg}$ ) and $2 \mathrm{ml}$ of a solvent containing $62.5 \%$ aqueous methanol and $6 \mathrm{M} \mathrm{HCl}(4: 1 \mathrm{vol} / \mathrm{vol})$ were suspended in a Pyrex tube with a Teflon-coated cover, placed under nitrogen gas flow to prevent oxidation and incubated $30 \mathrm{~min}$ at $90^{\circ} \mathrm{C}$ with regular shaking. Samples were then cooled on ice and $1 \mathrm{ml}$ methanol was added. The tubes were vortexed and the extract passed through $0.45 \mu \mathrm{m}$ filters into HPLC vials.

\subsection{3 | Chromatographic analysis of banana crown methanolic extracts}

\section{GC-MS analysis}

GC-MS analyses were performed on a HP-6890 GC system coupled with a $5973 \mathrm{~N}$ mass detector and equipped with a HP-5MS fused silica capillary column ( $30 \mathrm{~m} \times 0.25 \mathrm{~mm}, 0.25 \mu \mathrm{m}$ film thickness). Injection temperature was $230^{\circ} \mathrm{C}$, the interface set to $250^{\circ} \mathrm{C}$ and the ion source adjusted to $180^{\circ} \mathrm{C}$. The temperature programme started at $70^{\circ} \mathrm{C}$ for $5 \mathrm{~min}$, followed by a $5^{\circ} \mathrm{C} / \mathrm{min}$ temperature ramp up to 300 and $310^{\circ} \mathrm{C}$ was maintained for $1 \mathrm{~min}$. The system was then equilibrated at $70^{\circ} \mathrm{C}$ for 6 min before the next injection. The flow rate of helium, the carrier gas, was $1 \mathrm{ml} / \mathrm{min}$. Mass spectra were recorded at 2 scans/s with an $\mathrm{m} / \mathrm{z}$ 50-600 scanning range. Two microlitres of sample was used for analysis. The chromatograms and mass spectra were evaluated using the MSD ChemStation program (Hewlett Packard). Dopamine, epinephrine, norepinephrine, and normetanephrine (Sigma) were used as standards. The extracts were spiked with dopamine, epinephrine, norepinephrine, and normetanephrine, and estimated recoveries were $78 \%, 65 \%, 83 \%$, and $80 \%$ respectively. Each catecholamine was quantified by internal standardization with ribitol and their respective calibration curve, using the following ions: ribitol ( $\mathrm{m} / \mathrm{z} 307$; 319), dopamine ( $\mathrm{m} / \mathrm{z}$ 174; 338; 426), epinephrine ( $\mathrm{m} / \mathrm{z} 174 ; 294 ; 355)$, norepinephrine ( $\mathrm{m} / \mathrm{z} 174 ; 355$; 514), normetanephrine ( $\mathrm{m} / \mathrm{z}$ 174; 297; 456).

\section{HPLC analysis}

HPLC analyses were performed on an Agilent HP 1100 system using a C18 Inertsil ODS2 $(250 \times 2.1 \mathrm{~mm}, 5 \mu \mathrm{m})$ reverse phase analytical column with a diode array detector. Phenolic compounds were monitored at five wavelengths: 254, 280, 330, 366, and $450 \mathrm{~nm}$ and the peak spectra were recorded. Fluorescence detection was also carried out with an excitation wavelength of $305 \mathrm{~nm}$ and emission at $410 \mathrm{~nm}$. Methanolic extracts were separated with a mobile phase consisting of acetonitrile and Milli-Q water acidified at $\mathrm{pH} 3.0$ with phosphoric acid and a flow rate of $0.3 \mathrm{ml} / \mathrm{min}$ at $35^{\circ} \mathrm{C}$. A gradient of acetonitrile was programmed (0\% for $5 \mathrm{~min}$, increase to $50 \%$ in $70 \mathrm{~min}, 50 \%$ to $100 \%$ in $3 \mathrm{~min}$, and $100 \%$ for $7 \mathrm{~min}$ ). The column was then re-equilibrated with $0 \%$ acetonitrile for $10 \mathrm{~min}$. The volume of extracts injected into the column was $20 \mu \mathrm{l}$. Retention time $\left(t_{R}\right)$ and UV absorption spectra of the peaks of the extracts were compared with the ones obtained with the phenolic standards from SigmaAldrich, (ascorbic, gallic, chlorogenic, caffeic, coumaric, ferulic, and sinapic acids; catechin, rutin, and naringin) and Fluka (hesperidin, phloridzin, quercetin, cinnamic acid, naringenin, and kaempferol), previously prepared under the same conditions as crown samples to monitor degradation and avoid underestimation, and analysed under the same HPLC conditions in order to confirm their identification. The identified compounds were quantified by external calibration with the corresponding standard. The unidentified compounds were quantified in dopamine equivalents and the hydroxycinnamic acids in ferulic acid equivalents.

\section{LC-MS analysis}

LC-MS analyses were carried out with an Agilent HP 1100 system coupled to an HCT mass spectrometer (Bruker Daltonics) to corroborate the identifications made by HPLC. The extracts were diluted with methanol in order to obtain a total concentration of $10 \mu \mathrm{g} / \mathrm{ml}$. The column and elution gradient used were the same as described above for the HPLC-UV analysis. After the column, the flow was split and $0.05 \mathrm{ml} / \mathrm{min}$ was sent to the source for electrospray ionization (ESI). Column effluent was monitored in negative and positive ion modes. The ESI conditions were: $\mathrm{N}_{2}$ pressure $=35 \mathrm{psi}, \mathrm{N}_{2}$ flow 
rate $=8.5 \mathrm{~L} / \mathrm{min}$, and $365^{\circ} \mathrm{C}$. The ionic trap was set to scan from 150 to $1,000 \mathrm{~m} / \mathrm{z}$ (scan rate of $26,000 \mathrm{~m} / \mathrm{z} / \mathrm{s}$ ). The trap was emptied either after 200 ms or as soon as a total ionic current of 100,000 was reached. The $t_{R}$ and mass spectra of the peaks of the extracts were compared with those of standards previously analysed under the same LC-MS conditions in order to confirm their identification.

\section{5 | Statistical analysis}

The effects of severe So-Si ratio modifications on banana susceptibility to crown rot were analysed by the subjection of INS values calculated for the three clusters and each fruit grade and length values to a partially nested mixed three-way analysis of variance (ANOVA; Minitab v. 15.1). Each tree was taken as an experimental unit, and treatment, week, and bunch as factors. Multiple comparisons of the different means were performed by applying Tukey's test at a 5\% probability level. Data of crown phenolics quantified by HPLC analyses were subjected to a two-way ANOVA (Minitab v. 15.1), with treatment and stage as factors.

\section{3 | RESULTS}

\subsection{Effects of severe So-Si ratio modification on susceptibility to crown rot and on some fruit and tree characteristics}

The modifications of the So-Si ratio at flowering had a highly significant effect $(p<.001)$ on susceptibility of bananas to crown rot disease (Table 1). The level of fruit susceptibility decreased with increasing So-Si ratio (Figure 3). The highest INS average value of $524.0 \mathrm{~mm}^{2}$ was obtained with the lower So-Si ratio $(1 \mathrm{~L} / 8 \mathrm{H}$, So-Si ratio $=0.08)$ and the lowest value of $246.2 \mathrm{~mm}^{2}$ was obtained with the higher So-Si ratio $(12 \mathrm{~L} / 1 \mathrm{H}$, So-Si ratio $=8$; Table 2). Samples of these extreme treatments $(12 \mathrm{~L} / 1 \mathrm{H}$ and $1 \mathrm{~L} / 8 \mathrm{H})$ with differential susceptibilities to crown rot were then selected for chromatographic analyses.

The severe So-Si ratio modifications, which occurred during flowering, had a very significant effect $(p<.001)$ on grade and length of fruits distinguishing three statistically different groups amongst treatments (Table 3). Grade and fruit length increased with increasing So-Si ratio.

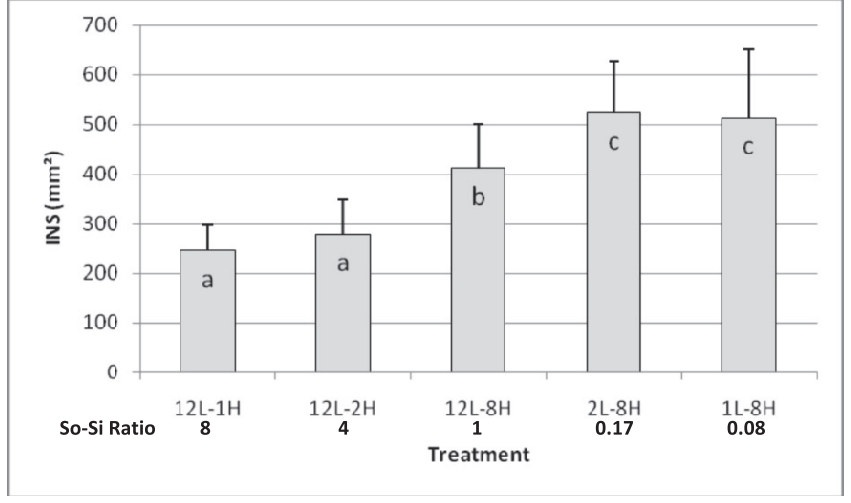

FIGURE 3 Effect of source-sink ratio modifications on the susceptibility of bananas to crown rot disease. The area of the internal necrotic surfaces (INS) were evaluated at 13 days postinoculation (13 dpi). Each bar represents the average of 15 replicates and $S D$ is shown. $L$, leaves; $\mathrm{H}$, hand

TAB LE 2 Susceptibility level of banana crown samples used for chromatographic analysis

\begin{tabular}{|c|c|c|c|c|}
\hline \multirow[b]{2}{*}{ Sample } & \multicolumn{2}{|c|}{ INS for GC-MS $\left(\mathrm{mm}^{2}\right)$} & \multicolumn{2}{|c|}{$\begin{array}{l}\text { INS for HPLC \& } \\
\text { LC-MS }\left(\mathrm{mm}^{2}\right)\end{array}$} \\
\hline & S- & $\mathrm{S}_{+}$ & S- & $\mathrm{S}_{+}$ \\
\hline 1 & 294 & 513 & 252 & 646 \\
\hline 2 & 176 & 494 & 264 & 620 \\
\hline 3 & 252 & 560 & 231 & 576 \\
\hline
\end{tabular}

Note: Samples for GC-MS analyses, and for HPLC and LC-MS analyses were collected in two different replicate experiments.

Abbreviations: INS, internal necrotic surface; S-, low susceptibility; S+, high susceptibility.

\section{2 | Phenolic constituents of banana with differential susceptibility to crown rot disease}

\subsection{1 | Analysis of standard products}

The HPLC method enabled a good separation of the 20 phenolic standards (see SolC $t_{R}$ in Table 4, which corresponds to the $t_{R}$ of the pure compounds), except for catecholamines that eluted in the same peak and could not be separated. Our LC-MS conditions allowed the

\begin{tabular}{|c|c|c|c|c|c|c|c|}
\hline \multirow[b]{2}{*}{ Source } & \multirow[b]{2}{*}{$d f$} & \multicolumn{2}{|l|}{$\mathrm{INS}^{\mathrm{a}}$} & \multicolumn{2}{|l|}{ Grade $^{b}$} & \multicolumn{2}{|l|}{ Length ${ }^{c}$} \\
\hline & & $F$ & $p$ & $F$ & $p$ & $F$ & $p$ \\
\hline Treatment & 4 & 24.25 & $<.001$ & 121.66 & .001 & 121.20 & $<.001$ \\
\hline Week & 2 & 8.88 & .001 & 1.99 & .151 & 1.29 & .288 \\
\hline Treatment $\times$ week & 8 & 2.36 & .035 & 0.33 & .948 & 2.38 & .034 \\
\hline Bunch (treatment) & 20 & 1.77 & .062 & 1.10 & .383 & 1.60 & .104 \\
\hline
\end{tabular}

TABLE 1 Analysis of variance of the effect of modification of source-sink ratio on susceptibility of banana to crown rot disease

anternal necrotic surface $\left(\mathrm{mm}^{2}\right)$.

${ }^{\mathrm{b}}$ Fruit grade (diameter in $\mathrm{mm}$ ).

'Length of fruit (cm). 
TAB LE 3 Mean values and standard deviations of some tree and fruit characteristics: fruit grade (diameter), fruit length, and number of leaves at harvest (NLH), for various source-sink ratio modifications

\begin{tabular}{lllll}
\hline Treatment & $\begin{array}{l}\text { Source-sink } \\
\text { ratio }\end{array}$ & Grade $(\mathrm{mm})$ & Length $(\mathrm{cm})$ & NLH \\
\hline $12 \mathrm{~L} / 1 \mathrm{H}$ & 8.00 & $39.0 \pm 1.5 \mathrm{a}$ & $33.1 \pm 1.4 \mathrm{a}$ & 6.9 \\
\hline $12 \mathrm{~L} / 2 \mathrm{H}$ & 4.00 & $38.3 \pm 1.5 \mathrm{a}$ & $32.3 \pm 1.4 \mathrm{a}$ & 6.7 \\
\hline $12 \mathrm{~L} / 8 \mathrm{H}$ & 1.00 & $34.8 \pm 1.2 \mathrm{~b}$ & $29.5 \pm 1.1 \mathrm{~b}$ & 6.2 \\
\hline $2 \mathrm{~L} / 8 \mathrm{H}$ & 0.17 & $30.1 \pm 1.3 \mathrm{c}$ & $25.3 \pm 0.7 \mathrm{c}$ & 2.0 \\
\hline $1 \mathrm{~L} / 8 \mathrm{H}$ & 0.08 & $29.5 \pm 1.8 \mathrm{c}$ & $24.7 \pm 1.4 \mathrm{c}$ & 1.0 \\
\hline
\end{tabular}

Note: Means are the result obtained after 3 weeks here represented with standard deviation in the table. The different letters represent groups showing statistically significant differences.

Abbreviations: $\mathrm{H}$, hands or clusters of fruit; $\mathrm{L}$, leaves.

detection and confirmed the identification of only 16 of these standards not submitted to acid hydrolysis; the $\mathrm{m} / \mathrm{z}$ of the base peak of the spectra, which correspond to the $[\mathrm{M}-\mathrm{H}]^{-}$ion are presented in Table 4 (SolC $\left.[\mathrm{M}-\mathrm{H}]^{-}\right)$. The $t_{R}$ of standards identified with HPLC was no different from that obtained with LC-MS. Under the conditions used for extraction of the bound fraction of phenolic compounds (acid hydrolytic conditions, $\mathrm{AHC}$ ), some of the standards gave one chromatographic peak at the same $t_{R}$, as found with extraction conditions used for the soluble phenolics (Table 4). It was assumed that the hydrolytic conditions did not affect these molecules (dopamine, epinephrine, norepinephrine, normetanephrine, quercetin, naringenin, and kaempferol). However, such extraction conditions modified the chemical composition of other compounds like gallic acid, catechin, caffeic acid, coumaric acid, ferulic acid, sinapic acid, naringin, and cinnamic acid, for which two peaks were observed after they had been subjected to hydrolytic conditions. One peak corresponded to the unmodified standard (almost the same $t_{R}$ ) and the other to an acid extraction by-product (Table 4). For chlorogenic acid, in addition to the unmodified molecule, two supplementary peaks were detected.

The GC-MS method allowed a good separation, identification, and quantification of the four catecholamines under study (dopamine, epinephrine, norepinephrine, and normetanephrine; Figure 4).

\subsubsection{Analysis of free soluble fraction compounds}

For the extracts of soluble phenolics (ESP), HPLC profiles were very similar for both treatments ( $\mathrm{S}+$ and $\mathrm{S}-$ ) and both stages (dhbi and $13 \mathrm{dpi}$ ). Only one major compound was eluted, with approximately the same amount for all treatments, after 2.5 min (peak 1). It was identified as catecholamine by comparison of its $t_{R}$, UV spectrum and major $\mathrm{m} / \mathrm{z}$ (152) observed in ESI-MS (negative mode) with those obtained from the pure catecholamine standard. However, in the chromatographic profile of the ESP, this catecholamine peak coeluted with ascorbic acid (Figure 5). Due to poor resolution, catecholamine was not quantified with this method.
The catecholamine presence in the methanolic extracts of crowns was clearly confirmed through GC-MS analysis on the basis of the $t_{R}$ and mass spectra of their standards (Figure 4). For both stages studied (dhbi and $13 \mathrm{dpi}$ ), dopamine content was not significantly $(p>.05)$ different in the S- $(12 \mathrm{~L} / 1 \mathrm{H})$ and $\mathrm{S}+(1 \mathrm{~L} / 8 \mathrm{H})$ crown samples (Table 5). Norepinephrine and normetanephrine contents significantly $(p<.05)$ differed between the $\mathrm{S}-$ and $\mathrm{S}+$ banana crowns at harvest stage (dhbi); their average amount was six and two times higher, respectively, in the S+ banana crowns than in the S- crowns (Table 5). Their concentration decreased strongly in banana crowns analysed $13 \mathrm{dpi}$. They were detected in very low amounts at unquantifiable concentrations. Epinephrine was not detected in banana crowns. Octopamine, another derivative of tyrosine, and other polar metabolites such as phenolic acids, carbohydrates (polysaccharides), free amino acids, fatty acids, phytosterols and derivatives were also identified in the crown extracts (not shown).

\subsubsection{Analysis of the bound fraction of phenolic compounds}

HPLC chromatograms obtained from the extracts of the bound phenolics (EBP) of the S- and S+ treatments at both stages (dhbi and $13 \mathrm{dpi}$ ) are shown in Figure 6. These chromatographic profiles differ quantitatively, but not qualitatively. Ten major peaks, all common to both treatments and both stages, were detected (peaks 1-10 in Figure 6).

Peak 1 was the major compound detected and was identified as catecholamine, as for the ESP, by its $t_{R}$, UV spectrum, major $\mathrm{m} / \mathrm{z}$ (152) observed in ESI-MS, and GC-MS analysis. The UV spectra from compounds of peaks 2-10 are shown in Figure 7. Compounds 2-4 had maxima in their spectrum at $280 \mathrm{~nm}$ and compounds 5-10 close to $310-330 \mathrm{~nm}$. Peaks 2-4 were quantified in dopamine equivalents $\left(\lambda_{\max } 280 \mathrm{~nm}\right)$ while peaks $5-10$ in ferulic acid equivalents $\left(\lambda_{\max }\right.$ $330 \mathrm{~nm})$. Vanillin and rutin were detected in traces, as well as traces of many other phenolic and derivatives (not shown).

The UV/visible spectra of peaks $2\left(t_{R} 16 \mathrm{~min}\right)$ and $3\left(t_{R} 27 \mathrm{~min}\right)$ were closest to the those of cinnamic acid amongst the 20 phenolic standards but did not correspond exactly to any of them (Figure 7) and had very different retention times from cinnamic acid (51 and 69 min under hydrolytic conditions). In addition, the spectrum of peak 4 was closest to that of gallic acid. However, this peak had a retention time (29 $\mathrm{min}$ ) very different from gallic acid (12 and $26 \mathrm{~min}$ ). The base peak obtained for the ESI-MS spectra (negative mode) of peaks 2, 3, and 4 were respectively ions of $\mathrm{m} / \mathrm{z} 531,545$, and 143 (Table 6). Peak 2 is not a distinct peak but a large one, which seems to be constituted by more than one product. The compounds in peaks 2,3 , and 4 could not be assigned to any of the standards used here (Figure 7, Table 6).

Peaks 5 and 9 had the same $t_{R}$, UV spectra, and base peaks in ESI-MS ( $\mathrm{m} / \mathrm{z} 163$ and $\mathrm{m} / \mathrm{z}$ 177, attributed to $[\mathrm{M}-\mathrm{H}]^{-}$) to those of coumaric acid standard and its acid extraction by-product (coumaric acid methyl ester), respectively. Coumaric acid methyl ester probably resulted from the methylation of the acid by the methanol used for the extraction in the presence of $\mathrm{HCl}$. Therefore, peaks 5 and 9 
TAB LE 4 HPLC retention time $\left(t_{R}\right)$ and LC-MS spectral information of phenolic standards separated on the Inertsil ODS 2 column under soluble conditions (SolC) and after acid hydrolytic conditions (AHC)

\begin{tabular}{|c|c|c|c|c|c|c|c|}
\hline \multirow[b]{2}{*}{ No. } & \multirow[b]{2}{*}{ Standard } & \multirow[b]{2}{*}{ Formula } & \multirow[b]{2}{*}{$\begin{array}{l}\text { Molar } \\
\text { mass }\end{array}$} & \multicolumn{2}{|c|}{ HPLC analysis LC-MS analysis } & \multirow[b]{2}{*}{$\begin{array}{l}\text { SolC } \\
{[\mathrm{M}-\mathrm{H}]^{-}}\end{array}$} & \multirow[b]{2}{*}{$\mathrm{AHC}[\mathrm{M}-\mathrm{H}]^{-}$} \\
\hline & & & & $\begin{array}{l}\operatorname{SolC~}_{R} \\
\text { (min) }\end{array}$ & $A H C t_{R}(\min )$ & & \\
\hline 1 & Dopamine $^{a}$ & $\mathrm{C}_{8} \mathrm{H}_{11} \mathrm{NO}_{2}$ & 153.08 & 2.5 & 2.5 & 151.8 & 151.9 \\
\hline 2 & Norepinephrine $^{a}$ & $\mathrm{C}_{8} \mathrm{H}_{11} \mathrm{NO}_{2}$ & 153.08 & 2.5 & 2.5 & ND & ND \\
\hline 3 & Epinephrine $^{a}$ & $\mathrm{C}_{9} \mathrm{H}_{13} \mathrm{NO}_{3}$ & 183.09 & 2.5 & 2.5 & ND & ND \\
\hline 4 & Normetanephrine ${ }^{a}$ & $\mathrm{C}_{9} \mathrm{H}_{13} \mathrm{NO}_{3}$ & 183.09 & 2.5 & 2.5 & ND & ND \\
\hline 5 & Ascorbic acid & $\mathrm{C}_{6} \mathrm{H}_{8} \mathrm{O}_{6}$ & 176.03 & $4.1-5.7$ & ND & 174.7 & ND \\
\hline 6 & Gallic acid & $\mathrm{C}_{7} \mathrm{H}_{6} \mathrm{O}_{5}$ & 170.02 & 11.5 & $11.8,25.8$ & 168.9 & $168.9,182.7$ \\
\hline 7 & Catechin & $\mathrm{C}_{15} \mathrm{H}_{14} \mathrm{O}_{6}$ & 290.08 & 27.0 & $27.0,45.8$ & 288.9 & $288.9,427.0$ \\
\hline 8 & Chlorogenic acid & $\mathrm{C}_{16} \mathrm{H}_{18} \mathrm{O}_{9}$ & 354.10 & 28.1 & $28.6,35.7,41.6$ & 352.9 & ND, 366.9, ND \\
\hline 9 & Caffeic acid & $\mathrm{C}_{9} \mathrm{H}_{8} \mathrm{O}_{4}$ & 180.04 & 28.5 & $28.8,43.5$ & 178.9 & $179,192.7$ \\
\hline 10 & Coumaric acid & $\mathrm{C}_{9} \mathrm{H}_{8} \mathrm{O}_{3}$ & 164.05 & 34.2 & $33.5,51.1$ & 162.9 & ND, 176.7 \\
\hline 11 & Ferulic acid & $\mathrm{C}_{10} \mathrm{H}_{10} \mathrm{O}_{4}$ & 194.06 & 36.7 & $36.7,52.9$ & 192.9 & $192.5,377.9$ \\
\hline 12 & Sinapic acid & $\mathrm{C}_{11} \mathrm{H}_{12} \mathrm{O}_{5}$ & 224.07 & 37.2 & $37.2,52.4$ & 222.8 & $222.6,236.6$ \\
\hline 13 & Rutin & $\mathrm{C}_{27} \mathrm{H}_{30} \mathrm{O}_{16}$ & 610.15 & 38.7 & 51.2 & 609.1 & ND \\
\hline 14 & Naringin & $\mathrm{C}_{27} \mathrm{H}_{32} \mathrm{O}_{14}$ & 580.18 & 41.8 & $42.3,55.1$ & 579.2 & $270.9,433.0$ \\
\hline 15 & Hesperidin & $\mathrm{C}_{28} \mathrm{H}_{34} \mathrm{O}_{15}$ & 610.19 & 42.8 & 57.8 & 609.1 & ND \\
\hline 16 & Phloridzin & $\mathrm{C}_{21} \mathrm{H}_{24} \mathrm{O}_{10}$ & 436.14 & 44.5 & 58.5 & 435.0 & ND \\
\hline 17 & Quercetin & $\mathrm{C}_{15} \mathrm{H}_{10} \mathrm{O}_{7}$ & 302.04 & 50.7 & 50.7 & 300.9 & ND \\
\hline 18 & Cinnamic acid & $\mathrm{C}_{9} \mathrm{H}_{8} \mathrm{O}_{2}$ & 148.05 & 51.2 & $51.4,69.1$ & ND & ND, ND \\
\hline 19 & Naringenin & $\mathrm{C}_{15} \mathrm{H}_{12} \mathrm{O}_{5}$ & 272.07 & 55.3 & 55.3 & 271.0 & ND \\
\hline 20 & Kaempferol & $\mathrm{C}_{15} \mathrm{H}_{10} \mathrm{O}_{6}$ & 286.05 & 57.5 & 57.3 & 284.9 & 285.0 \\
\hline
\end{tabular}

Abbreviation: ND, not detected.

${ }^{\text {a } C a t e c h o l a m i n e . ~}$

were identified as coumaric acid and its methyl ester, respectively (Figure 7, Table 6).

Similarly, peaks 6 and 10 had the same $t_{R}$ (36.9 and $52.9 \mathrm{~min}$ ), UV spectra, and base peaks in ESI-MS (m/z 193 and m/z 378, attributed to $\left.[\mathrm{M}-\mathrm{H}]^{-}\right)$as the ferulic acid standard and its acid extraction by-product, respectively. Therefore, peaks 6 and 10 were identified by HPLC, UV, and LC-MS as ferulic acid and its acid extraction by-product, respectively (Figure 7, Table 6).

Peaks $7\left(t_{R} 41.0 \mathrm{~min}\right)$ and $8\left(t_{R} 41.7 \mathrm{~min}\right)$ had the same UV spectrum as chlorogenic acid. However, the retention times of these two peaks, as well as the results of the LC-MS analysis, could not corroborate the nature of these products (Figure 7, Table 6).

Overall, most phenolic compounds had higher contents in Scrowns than in S+ crowns, and their content was also higher in crowns at harvest stage (dhbi) than at $13 \mathrm{dpi}$ (Table 7).

The product present in peak 2 was the second most important compound in the EBP after peak 1 (catecholamines). Its amount was significantly higher $(p=.014)$ in the S- crowns than the S+ crowns on the day of harvest (dhbi): 153.8 and $15.6 \mu \mathrm{g}$ dopamine equivalents per g FW respectively. Its level significantly decreased $(p=.044)$ at $13 \mathrm{dpi}$ to 36.4 and $4.3 \mu \mathrm{g}$ dopamine equivalents per $\mathrm{g} \mathrm{FW}$ for $\mathrm{S}-$ and S+ crowns, respectively (Table 7).
For samples from dhbi, the amount of phenolic compounds accumulated in the $\mathrm{S}$ - crown samples as compared to the $\mathrm{S}+$ ones were significantly higher $(p<.05)$ in peak 3 and peak 5 (coumaric acid), and more significantly higher $(p<.001)$ in peak 6 (ferulic acid), peak 10 (ferulic acid extraction by-product), peak 7 , and peak 8 . For peak 4 and peak 9 (methyl ester of coumaric acid), no significant difference was noticed between $\mathrm{S}-$ and the $\mathrm{S}+$ crown samples (Table 7).

At $13 \mathrm{dpi}$, the amount of phenolic compound was significantly lower $(p<.05)$ than at the dhbi stage for peak 6 (ferulic acid), peak 10 (ferulic acid extraction by-product), peak 7 , and peak 8 . This decrease was more important for $\mathrm{S}+$ crown samples. For peak 3 , the decrease was most pronounced in the $\mathrm{S}$ - crown samples (Table 7). For peak 5 (coumaric acid), peak 4 , and peak 9 (methyl ester of coumaric acid) there was no significant difference $(p>.05)$ between either stage (dhbi and $13 \mathrm{dpi}$ ).

\section{4 | DISCUSSION}

The severe modification of So-Si ratio was found to influence the susceptibility of fruits to crown rot disease. Banana susceptibility to 


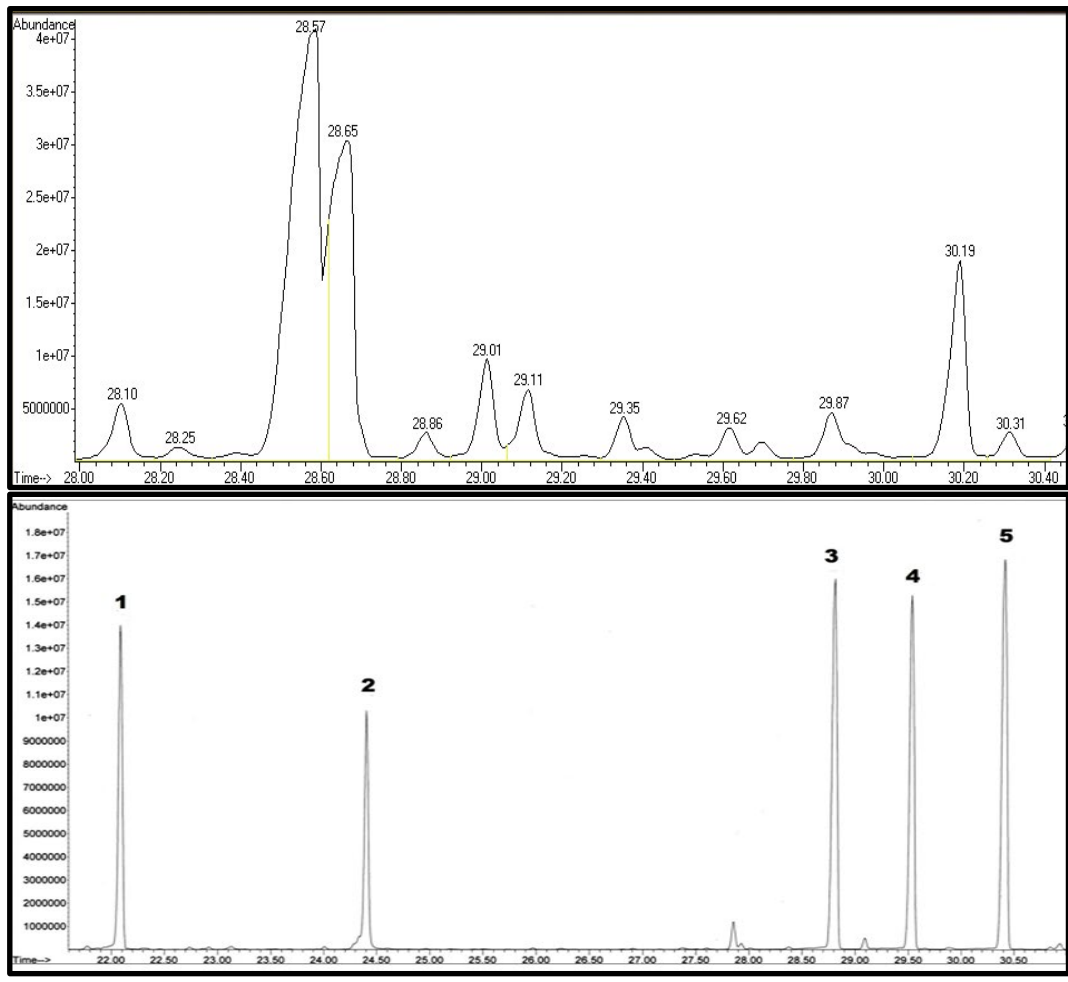

\begin{tabular}{|l|c|c|c|c|c|}
\hline Peak N & 1 & 2 & 3 & 4 & 5 \\
\hline $\mathbf{R}_{\mathbf{T}}(\mathbf{m i n})$ & 22.09 & 24.40 & 28.78 & 29.52 & 30.39 \\
\hline $\mathrm{m} / \mathbf{z}(\mathbf{)}$ & $307 ; 319$ & $174 ; 294 ; 355$ & $174 ; 338 ; 426$ & $174 ; 355 ; 514$ & $174 ; 297 ; 456$ \\
\hline
\end{tabular}

FIGURE 4 GC-MS profiles of banana crown extract between 28 and 30.5 min retention time (a) and catecholamines standards from Sigma from 22 to 30.5 min (b). 1, Ribitol (internal standard); 2, epinephrine; 3, dopamine; 4, normetanephrine; 5, norepinephrine

FIGURE 5 HPLC chromatogram at $280 \mathrm{~nm}$ of soluble methanolic fraction of banana crown between 0 and $10 \mathrm{~min}$ retention time. Chromatograms of phenolic compounds present in the susceptible banana crown sample $(\mathrm{S}+$, blue) are superimposed on those from the less susceptible banana crown sample (S-, red). Identities of the known peaks are indicated

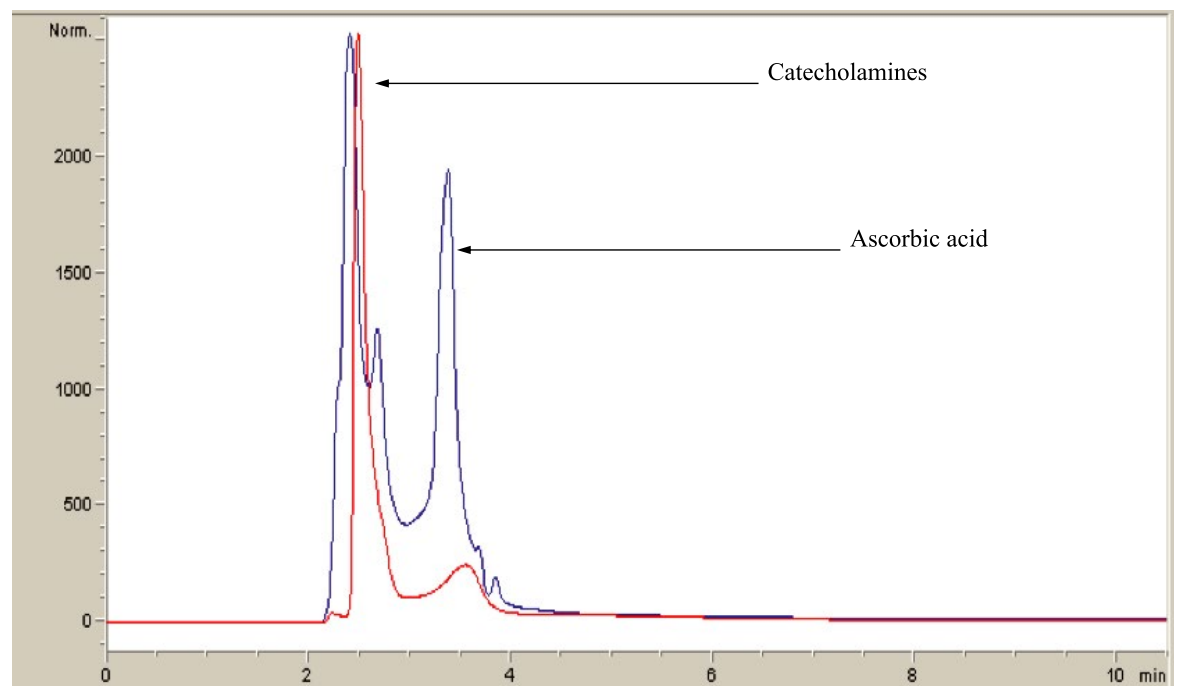

this postharvest disease increased when the So-Si ratio was severely decreased. Our results are in accordance with those of Lassois et al. (2010b) that revealed a similar effect of So-Si ratio modifications. However, in our study we explored a broader range of So-Si ratio modifications, from $12 \mathrm{~L} / 1 \mathrm{H}(\mathrm{So}-\mathrm{Si}=8$ ) to $1 \mathrm{~L} / 8 \mathrm{H}(\mathrm{So}-\mathrm{Si}=0.08)$, than former studies $(12 \mathrm{~L} / 2 \mathrm{H}$, So-Si $=4$ to $5 \mathrm{~L} / 8 \mathrm{H}$, So-Si $=0.4)$. In such extreme conditions, the differences between susceptible $\left(\mathrm{S}_{+}\right)$and less susceptible (S-) fruits were more pronounced and sufficient to allow a differential study of phenolics. As expected, the removal of some hands at flowering reduced fruit susceptibility (Lassois et al., $2010 b)$. In the same way, severe defoliations led to an increase of fruit susceptibility. In a previous study, we showed that black leaf streak disease (BLSD) increased banana susceptibility to crown rot disease (Ewané et al, 2013). BLSD is a foliar disease that might cause severe defoliation levels (comparable to treatments $2 \mathrm{~L} / 8 \mathrm{H}$ and $1 \mathrm{~L} / 8 \mathrm{H}$; So-Si ratio 0.17 and 0.08 , respectively) in commercial banana 
farms and would then lead to an important increase of fruit susceptibility to crown rot. Our results in the present study support the fact that, besides already reported impacts of BLSD on yield and fruit conservation (greenlife), this foliar disease might also affect other fruit quality traits.

Lassois et al. (2010b, 2011) hypothesized that modifications in So-Si ratio lead to a change in partitioning of assimilates between various sinks, which would influence the formation of secondary metabolites involved in a plant-pathogen interaction. Our results support such a hypothesis because there were significantly higher amounts of phenolic compounds in less susceptible fruits (S-). This is the first study dedicated to the evaluation of phenolic compounds in banana crowns and to their possible involvement as a plant defence mechanism to crown rot disease.

Among the 10 phenolic compounds identified in the EBP from crown tissues, only five (corresponding to peaks 1, 5, 6, 9, and 10) could be identified: catecholamines (peak 1), coumaric acid (peaks 5 and 9), and ferulic acid (peaks 6 and 10). Coumaric acid and ferulic acid might play a significant role in lower crown rot susceptibility because their amounts were significantly higher in S- fruits at harvest stage and their content decreased significantly in S- fruits 13 days after infection. Indeed, such compounds and their conjugates have been previously identified in banana tissues, recently in banana peel (Manthey and Jaitrong, 2016), and have been related to defence mechanisms (Valette et al., 1998; Kanazawa and Sakakibara, 2000; de Ascensao and Dubery, 2003; Wuyts et al., 2007). Ferulic acid and its esters can be toxic for root nematodes (Wuyts et al., 2006) or bound to cell walls for their protection against enzymatic attacks (Wuyts et al., 2007). However, here, the amount of ferulic acid was more important in the banana crown samples than in the root samples. Coumaric acid and its methyl ester possess antifungal properties and increase after infection, being associated with phytoalexin-like behaviour in many plants (Daayf et al., 1997; Li et al., 2018; Yuan et al., 2019).

Compounds 2, 3, 4, 7, and 8 remain unknown. Compound 4 is likely to have an insignificant role in this pathosystem because its variation is poorly linked with fruit susceptibility. However, compounds $2,3,7$, and 8 probably play an important role in banana crown defence and should be further extracted, purified, and completely characterized by MS and nuclear magnetic resonance techniques. In this regard, compound 2 would require particular attention because it is at very high levels in the crowns of less susceptible fruits (S-) compared with susceptible fruits $\left(\mathrm{S}_{+}\right)$and could be a potential marker for crown rot susceptibility.

There are good reasons to speculate that all phenolic compounds in banana crowns may create a toxic environment for fungal invasion and growth, notably in the S- crown samples. Indeed, the hydroxycinnamic acids and their derivatives ( $p$-coumaric, ferulic) serve as precursors for a wide variety of chemically diverse phenylpropanoid derivatives with antimicrobial functions, such as the plant-specific phytoalexin hydroxycinnamic acid amides (HCAA) and flavonoids (Dixon et al., 2002; Facchini et al., 2002). Thus, the phenolic content of the banana crown could be part of the biochemical response mechanism to infection and may be involved in the variation of banana susceptibility. With LC-MS conditions used in the present study, it was not possible to identify all the phenolics involved in banana susceptibility to crown rot or test their fungicidal activity in vitro. Consequently, we cannot speculate on their particular antifungal properties.

The amount of most phenolic compounds decreased significantly from harvest (dhbi) to $13 \mathrm{dpi}$, especially in the $\mathrm{S}+$ crown. Possible maturation effects could explain this decrease because previous authors have mentioned that the amount of phenolics decreases during fruit ripening (Kanazawa and Sakakibara, 2000). Given that all phenolic compounds were present in uninfected banana crowns (dhbi) and that their amount decreased after inoculation, they should be considered as constitutive compounds and not induced. However, the evaluation of the synthesis of induced compounds 13 days after inoculation is probably too late for the assessment of biochemical events occurring in banana crown tissues in the first hours and days after inoculation and the establishment of infections.

Catecholamines were found in the less susceptible ( $\left.\mathrm{S}^{-}\right)$as well as in the susceptible (S+) banana crowns. GC-MS enabled them to be identified as dopamine and its derivatives (norepinephrine and normetanephrine), while HPLC detected the presence of catecholamines in banana crowns without specific identification of the different compounds. The amounts of dopamine were similar in S- and $\mathrm{S}+$ fruits, while norepinephrine and normetanephrine contents were higher in susceptible fruits. Our result seems contradictory to a previous study where the overexpression of the dopamine- $\beta$-monooxygenase gene was highlighted in bananas less susceptible (S-) to crown rot (Lassois et al., 2011). However, another study has shown that the dopamine level did not differ between healthy and infected banana roots of resistant and susceptible cultivars (Wuyts et al., 2007). This reveals the degree of complexity of the regulation mechanisms for

TAB LE 5 GC-MS analysis of catecholamine contents for susceptible ( $\left.\mathrm{S}^{+}\right)$and less susceptible (S-) banana crowns at two sampling stages

\begin{tabular}{llll} 
Catecholamine & Treatment & $\begin{array}{l}\text { S- (mg/g } \\
\text { crown FW) }\end{array}$ & $\begin{array}{l}\text { S+ (mg/g } \\
\text { crown FW) }\end{array}$ \\
\hline Dopamine & dhbi & $\begin{array}{l}21.23 \pm 0.68 \\
\text { aA }\end{array}$ & $\begin{array}{l}19.76 \pm 0.29 \\
\text { aA }\end{array}$ \\
& 13 dpi & $20.46 \pm 0.28$ & $\begin{array}{l}17.91 \pm 2.00 \\
\text { aA }\end{array}$ \\
Norepinephrine & dhbi & $1.03 \pm 0.53 \mathrm{a}$ & $6.34 \pm 1.35 \mathrm{~b}$ \\
& $13 \mathrm{dpi}$ & - & - \\
Normetanephrine & $\mathrm{dhbi}$ & $1.73 \pm 0.09 \mathrm{a}$ & $3.22 \pm 0.58 \mathrm{~b}$ \\
& $13 \mathrm{dpi}$ & - & - \\
\hline
\end{tabular}

Note: Means are the result of three replicates $\pm S D$. Values followed by the same letter, lower case for treatment ( + +/S-) or upper case for sampling stages (dhbi/13 dpi), represent groups showing no statistically significant differences $(p<0.05)$.

Abbreviation: dhbi, day of harvest before inoculation; dpi, days postinoculation; FW, fresh weight. 

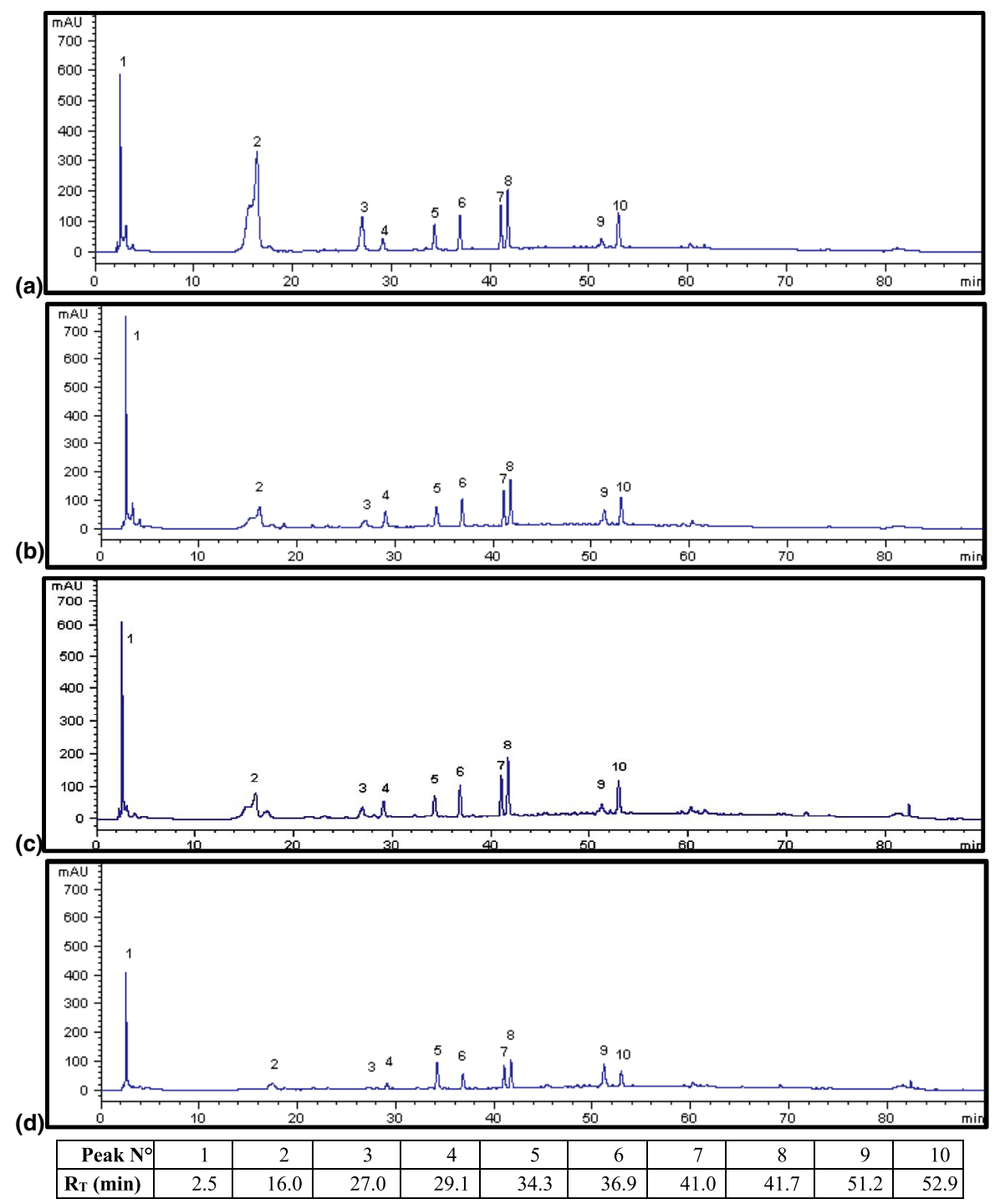

FIGURE 6 HPLC chromatogram at $280 \mathrm{~nm}$ of the bound methanolic fraction of banana crown for the different treatments (susceptible/ less susceptible [S+/S-]) and sampling stages (day of harvest before inoculation/13 days postinoculation [dhbi/13 dpi]). (a) $\mathrm{S}-/ \mathrm{dhbi}$, (b) $\mathrm{S}+/$ dhbi, (c) S-/13 dpi, and (d) S+/13 dpi. Numbers over the peak indicate: 1, catecholamines; 5, coumaric acid; 6, ferulic acid; 9, coumaric acid methyl ester; 10, ferulic acid $\mathrm{HCl}$ extraction by-product; $2,3,4,7$, and 8 indicate unknown phenolics

dopamine and its derivatives. Nevertheless, dopamine and its derivatives seem to be involved in the banana crown defence mechanism. Indeed, dopamine is an intermediate in the biosynthesis of benzylisoquinoline alkaloids (Trenchard et al., 2015) that can also form conjugates with phenolic acids like $p$-coumaryladrenaline, implicated in plant defence (Roepenack-Lahaye et al., 2003).

To conclude, the influence of severe So-Si ratio modifications on banana susceptibility to crown rot has been demonstrated, as well as the differential accumulation of phenolics in crown tissues. This is the first study dedicated to the evaluation of phenolic compounds in banana crowns and their possible involvement as a plant defence mechanism against crown rot disease; it is also the first report of catecholamine content in banana crowns. The results suggest an effect of So-Si ratio modifications on banana fruit quality potential in terms of phenolic accumulation, and present a useful implication that phenolics may be involved in the biochemical basis of variation in banana susceptibility to crown rot. Thus, this study represents a starting point for a better understanding of the function(s) of these intriguing molecules in the banana crown's defence mechanisms.

\section{ACKNOWLEDGEMENTS}

The authors wish to thank the agro-industries of Cameroon, Plantations du Haut Penja (PHP), for their collaboration on this project. We are especially thankful to the dedicated technical assistance of the Phytopathology Unit (Oscar Nguidjo, Robert Dongmo, Flauribert Tchipé, Sakio Kana, Joseph Essomé, Clément Essoh, Madeleine Ntombé, Henri Mpouli, Adolphe Moussissa, Lévi Noumtcheu, Thaddée Nkwe, and Thomas Mbock) and the Post-harvest Technology Unit (Jonas Tembe Tembe, Mama 

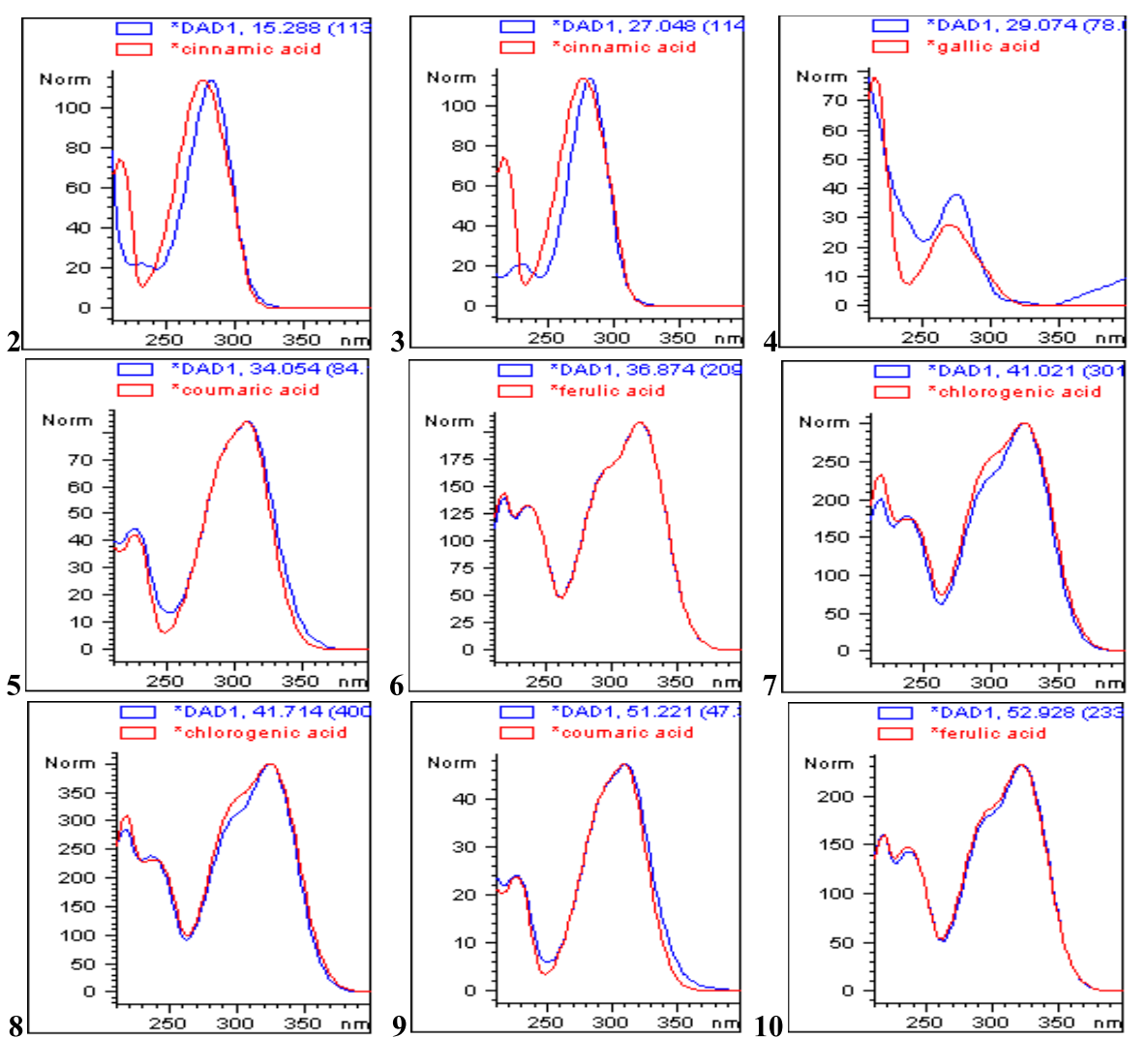

\begin{tabular}{|c|c|c|c|c|c|}
\hline Peak & $\begin{array}{l}\lambda_{\max } \\
(\mathrm{nm})\end{array}$ & $t_{R}(\min )$ & HPLC compound & {$[\mathrm{M}-\mathrm{H}]^{-}$} & $\begin{array}{l}\text { LC-MS } \\
\text { compound }\end{array}$ \\
\hline 1 & 280 & 2.5 & Catecholamine & 151.6 & $\begin{array}{l}\text { Dopamine } \\
{[\mathrm{M}-\mathrm{H}]^{-}}\end{array}$ \\
\hline 2 & 280 & 16.0 & Unknown & 530.7 & $\begin{array}{l}\text { Unknown } \\
{[\mathrm{M}-\mathrm{H}]^{-}}\end{array}$ \\
\hline 3 & 280 & 27.0 & Unknown & 544.8 & $\begin{array}{l}\text { Unknown } \\
{[\mathrm{M}-\mathrm{H}]^{-}}\end{array}$ \\
\hline 4 & 280 & 29.1 & Unknown & 142.5 & $\begin{array}{l}\text { Unknown } \\
{[\mathrm{M}-\mathrm{H}]^{-}}\end{array}$ \\
\hline 5 & 330 & 34.3 & Coumaric acid & 162.6 & $\begin{array}{l}\text { Coumaric acid } \\
{[\mathrm{M}-\mathrm{H}]^{-}}\end{array}$ \\
\hline 6 & 330 & 36.9 & Ferulic acid & 192.6 & $\begin{array}{l}\text { Ferulic acid } \\
{[\mathrm{M}-\mathrm{H}]^{-}}\end{array}$ \\
\hline 7 & 330 & 41.0 & Chlorogenic acid & 416.7 & $\begin{array}{l}\text { Unknown } \\
{[\mathrm{M}-\mathrm{H}+64]^{-}}\end{array}$ \\
\hline 8 & 330 & 41.7 & Chlorogenic acid & 338.7 & $\begin{array}{l}\text { Unknown } \\
{[\mathrm{M}-\mathrm{H}-14]^{-}}\end{array}$ \\
\hline 9 & 330 & 51.2 & Coumaric acid ME & 176.6 & $\begin{array}{c}\text { Coumaric acid } \\
\text { by-product }\end{array}$ \\
\hline 10 & 330 & 52.9 & Ferulic acid Eb & 377.6 & Ferulic acid Eb \\
\hline
\end{tabular}

Abbreviations: Eb, extraction by-product; ME, methyl ester.

Nkoundou, Raphael Tchokouassom, and Anne-Marie Toukam) of Centre Africain de Recherches sur Bananiers et Plantains (CARBAP) at Njombé for their excellent technical assistance in this project. Technical assistance from Vincent Hote and
FIGURE 7 UV spectra of HPLC peaks 2-10. DAD1, diode array detector 1. Absorbance $(A)=f(\lambda)$ obtained during identification of peaks. Spectra of phenolic compounds present in the banana crown sample (blue) are superimposed on those of the corresponding phenolic standard (red) measured under the same experimental conditions

TABLE 6 HPLC/LC-MS analysis data of phenolic compounds in banana crown extracts, according to their UV absorption spectra, retention time $\left(t_{R}\right)$, and their negative ionization mass spectra
Danny Trismann of the General and Organic Chemistry Unit and from Fabienne Piscard and Sophie Vancraenenbroeck of the Analytic Chemistry Unit at University of Liège-GxABT is equally acknowledged. 
TAB LE 7 Phenolic contents of the extracts of bound phenolics (EBP) for different susceptibility levels and sampling stages of banana crown

\begin{tabular}{|c|c|c|c|c|c|c|}
\hline \multirow[b]{2}{*}{ Peak } & \multirow[b]{2}{*}{ Compound } & \multirow[b]{2}{*}{ Stage } & \multirow{2}{*}{$\begin{array}{l}\text { Less susceptible crown } \\
\text { (S-) }\end{array}$} & \multirow{2}{*}{$\begin{array}{l}\text { Susceptible crown } \\
\text { (S+) }\end{array}$} & \multicolumn{2}{|l|}{$p$} \\
\hline & & & & & Treatment & Stage \\
\hline 2 & Unknown & $13 \mathrm{dpi}$ & $36.42 \pm 0.15$ ay & $4.30 \pm 0.01$ by & .014 & .044 \\
\hline 3 & Unknown & dhbi & $86.00 \pm 0.99 a x$ & $3.63 \pm 0.00 \mathrm{bx}$ & .032 & .051 \\
\hline \multirow[t]{2}{*}{4} & \multirow[t]{2}{*}{ Unknown } & dhbi & $5.60 \pm 0.03 a x$ & $5.89 \pm 0.01 \mathrm{ax}$ & \multirow[t]{2}{*}{.144} & \multirow[t]{2}{*}{.092} \\
\hline & & $13 \mathrm{dpi}$ & $5.56 \pm 0.03 a x$ & $1.81 \pm 0.01 \mathrm{ax}$ & & \\
\hline \multirow[t]{2}{*}{5} & \multirow[t]{2}{*}{ Coumaric acid } & dhbi & $11.86 \pm 0.05 a x$ & $7.26 \pm 0.02 b x$ & \multirow[t]{2}{*}{.008} & \multirow[t]{2}{*}{.057} \\
\hline & & $13 \mathrm{dpi}$ & $8.73 \pm 0.05 a x$ & $5.56 \pm 0.02 b x$ & & \\
\hline 6 & Ferulic acid & dhbi & $23.15 \pm 0.02 \mathrm{ax}$ & $12.23 \pm 0.02 b x$ & $<.001$ & $<.001$ \\
\hline \multirow[t]{2}{*}{7} & \multirow[t]{2}{*}{ Unknown } & dhbi & $27.82 \pm 0.08 \mathrm{ax}$ & $15.85 \pm 0.01 b x$ & \multirow[t]{2}{*}{$<.001$} & \multirow[t]{2}{*}{.008} \\
\hline & & 13 dpi & $20.92 \pm 0.05$ ay & $7.42 \pm 0.02$ by & & \\
\hline \multirow[t]{2}{*}{8} & \multirow[t]{2}{*}{ Unknown } & dhbi & $35.89 \pm 0.11$ ax & $20.17 \pm 0.02 b x$ & \multirow[t]{2}{*}{$<.001$} & \multirow[t]{2}{*}{.008} \\
\hline & & 13 dpi & $26.87 \pm 0.07$ ay & $9.28 \pm 0.02$ by & & \\
\hline \multirow[t]{2}{*}{9} & \multirow[t]{2}{*}{ Coumaric acid ME } & dhbi & $7.43 \pm 0.01 \mathrm{ax}$ & $7.31 \pm 0.01 \mathrm{ax}$ & .843 & .358 \\
\hline & & 13 dpi & $8.09 \pm 0.01 \mathrm{ax}$ & $7.94 \pm 0.02 \mathrm{ax}$ & & \\
\hline 10 & Ferulic acid Eb & dhbi & $38.32 \pm 0.10 \mathrm{ax}$ & $20.15 \pm 0.07 b x$ & $<.001$ & .001 \\
\hline & & $13 \mathrm{dpi}$ & $28.74 \pm 0.09$ ay & $9.38 \pm 0.03$ by & & \\
\hline
\end{tabular}

Note: Peak 6 is ferulate and expressed in $\mu \mathrm{g} / \mathrm{g}$ crown FW. Peaks 2, 3, and 4 are expressed in $\mu \mathrm{g}$ of dopamine equivalents/g FW while peaks 5, 7, 8 , 9 , and 10 are expressed in $\mu \mathrm{g}$ of ferulate equivalents/g FW. $p$ is the probability obtained with analysis of variance. Means are the result of three replicates $\pm S D$. The different letters $a$ and $b$ for treatment ( $+/ S-$ ), $x$ and $y$ for sampling stages (dhbi/13 dpi) represent groups showing statistically significant differences.

Abbreviation: ME, methyl ester; Eb, extraction by-product; dhbi, day of harvest before inoculation; dpi, days postinoculation; FW, fresh weight.

\section{DATA AVAILABILITY STATEMENT}

The data that support the findings of this study are available from the corresponding author upon reasonable request.

\section{ORCID}

Cecile A. Ewané iD https://orcid.org/0000-0001-5447-228X

\section{REFERENCES}

de Ascensao, A.R.F.D.C. and Dubery, I.A. (2003) Soluble and wall-bound phenolics and phenolic polymers in Musa acuminata roots exposed to elicitors from Fusarium oxysporum f.sp. cubense. Phytochemistry, 63, 679-686.

Beveraggi, A., Mourichon, X. and Sallé, G. (1995) Etude comparée des premières étapes de l'infection chez des bananiers sensibles et résistants infectés par Cercospora fijiensis, agent de la maladie des raies noires. Canadian Journal of Botany, 73, 1328-1337.

Chillet, M. andde Lapeyre de Bellaire, L. (1996) Elaboration de la qualité des bananes au champ. Détermination de critères de mesure. Fruits, 51, 317-326.

Collingborn, F.M.B., Gowen, S.R. and Mueller-Harvey, I. (2000) Investigations into the biochemical basis for nematode resistance in roots of three Musa cultivars in response to Radopholus similis infection. Journal of Agricultural and Food Chemistry, 48, 5297-5301.

Daayf, F., Bel-Rhlid, R. and Bélanger, R.R. (1997) Methyl ester of $p$-coumaric acid: a phytoalexin-like compound from long English cucumber leaves. Journal of Chemical Ecology, 23, 1517-1526.
Dixon, R.A., Achnine, L., Kota, P., Liu, C.J., Reddy, M.S.S. and Wang, L.J. (2002) The phenyl-propanoid pathway and plant defence - a genomics perspective. Molecular Plant Pathology, 3, 371-390.

El Hadrami, A. (1997) Proanthocyanidines constitutifs des feuilles de bananiers et résistance partielle vis-à-vis de Mycosphaerella fijiensis, l'agent causal de la maladie des raies noires. DEA thesis, Faculté Universitaire des Sciences Agronomiques, Gembloux, Belgium.

Ewané, C.A., Lepoivre, P., de Lapeyre de Bellaire, L. and Lassois, L. (2012a) Involvement of phenolic compounds in the susceptibility of bananas to crown rot. A review. Biotechnology Agronomy Society and Environment, 16, 393-404.

Ewané, C.A., Lassois, L., Brostaux, Y., Lepoivre, P. and de Lapeyre de Bellaire, L. (2012b) The susceptibility of bananas to crown rot disease is influenced by geographic and temporal effects. Canadian Journal of Plant Pathology, 35, 27-36.

Ewané, C.A., Chillet, M., Castelan, F., Brostaux, Y., Lassois, L., Ngando, E.J. et al. (2013) Impact of the extension of black leaf streak disease on banana susceptibility to post-harvest diseases. Fruits, 68, 351-365.

Facchini, P.J., Hagel, J. and Zulak, K.G. (2002) Hydroxycinnamic acid amide metabolism: physiology and biochemistry. Canadian Journal of Botany, 80, 577-589.

Finlay, A.R. and Brown, A.E. (1993) The relative importance of Colletotrichum musae as a crown rot pathogen on Windward Island bananas. Plant Pathology, 42, 67-74.

Jullien, A., Chillet, M. and Malezieux, E. (2008) Pre-harvest growth and development, measured as accumulated degree days, determine the 
post-harvest green life of banana fruit. Journal of Horticultural Science and Biotechnology, 83, 506-512.

Kamo, T., Kato, N., Hirai, N., Tsuda, M., Fujioka, D. and Ohigashi, H. (1998) Phenylphenalenone-type phytoalexins from unripe Bungulan banana fruit. Biosciences Biotechnology and Biochemistry, 62, 95-101.

Kamo, T., Hirai, N., Iwami, K., Fujioka, D. and Ohigashi, H. (2001) New phenylphenalenones from banana fruit. Tetrahedron, 57, 7649-7656.

Kanazawa, K. and Sakakibara, H. (2000) High content of dopamine, a strong antioxidant, in Cavendish banana. Journal of Agricultural and Food Chemistry, 48, 844-848.

Kavino, M., Kumar, N., Damodaran, T., Harish, S. and Saravanakumar, D. (2009) Biochemical markers as a useful tool for the early identification of Fusarium oxysporum f. sp. cubense, race 1 resistance banana clones. Archives of Phytopathology and Plant Protection, 42, 1069-1078.

Krauss, U. and Johanson, A. (2000) Recent advances in the control of crown rot of banana in the Windward Islands. Crop Protection, 19, 151-160.

de Lapeyre de Bellaire, L. and Nolin, J. (1994) Amélioration du contrôle du chancre sur les bananes d'exportation et traitements post-récolte. Fruits, 49, 179-185.

de Lapeyre de Bellaire, L., Chillet, M. and Chilin-Charles, Y. (2008) Measurement of fungicide efficacy on post-harvest diseases: wound anthracnose, quiescent anthracnose, crown rot. Fruits, 63, 303-306.

Lassois, L., Jijakli, M.H., Chillet, M. and de Lapeyre de Bellaire, L. (2010a) Crown rot of bananas: pre-harvest factors involved in post-harvest disease development and integrated control methods. Plant Disease, 94, 648-658.

Lassois, L., Baastianse, H., Chillet, M., Jullien, A., Jijakli, M.H. and de Lapeyre de Bellaire, L. (2010b) Hand position on the bunch and source-sink ratio influence the banana fruit susceptibility to crown rot disease. Annals of Applied Biology, 156, 221-229.

Lassois, L., Frettinger, P., de Lapeyre de Bellaire, L., Lepoivre, P. and Jijakli, M.H. (2011) Identification of genes involved in the response of banana to crown rot disease. Molecular Plant-Microbe Interactions, 24, 143-153.

Li, W., Yuan, S., Sun, J., Li, Q., Jiang, W. and Cao, J. (2018) Ethyl p-coumarate exerts antifungal activity in vitro and in vivo against fruit Alternaria alternata via membrane-targeted mechanism. International Journal of Food Microbiology, 278, 26-35.

Luis, J.G., Echeverri, F., Quinones, W., Brito, I., Lopez, M., Torres, F. et al. (1993) Irenolone and emenolone: two new types of phytoalexin from Musa paradisiaca. Journal of Organic Chemistry, 58, 4306-4308.

Manthey, J.A. and Jaitrong, S. (2016) An HPLC-MS analysis of phenolic antioxidants in banana peel. Proceedings of the Florida State Horticultural Society, 129, 181-184.

Muirhead, I.F. and Deverall, B.J. (1984) Evaluation of 3,4-dihydroxybenzaldehyde, dopamine and its oxidation products as inhibitors of Colletotrichum musae (Berk. \& Curt.) Arx. in green banana fruits. Australian Journal of Botany, 32, 375-382.

Nuratika, S.M.T., Ding, P. and Kadir, J. (2018) Controlling Musa AAA Berangan crown rot disease using UV-C irradiation. Acta Horticulturae, 1213, 603-608.

Roepenack-Lahaye, E., Newman, M.A., Schornack, S., Hammond Kosack, K.E., Lahaye, T., Jones, JDG et al. (2003) p-Coumaroylnoradrenaline, a novel plant metabolite implicated in tomato defence against pathogens. Journal of Biological Chemistry, 278, 43373-43383.

Slabaugh, W.R. and Grove, M.D. (1982) Postharvest diseases of bananas and their control. Plant Disease, 66, 746-750.

Someya, S., Yoshiki, Y. and Okubo, K. (2002) Antioxidant compounds from bananas (Musa Cavendish). Food Chemistry, 79, 351-354.

Szopa, J., Wilczynski, G., Fiehnb, O., Wenczel, A. and Willmitzerb, L. (2001) Identification and quantification of catecholamines in potato plants (Solanum tuberosum) by GC-MS. Phytochemistry, 58, 315-320.

Trenchard, I.J., Siddiqui, M.S., Thodey, K. and Smolke, C.D. (2015) De novo production of the key branch point benzylisoquinoline alkaloid reticuline in yeast. Metabolic Engineering, 31, 74-83.

Valette, C., Andary, C., Geiger, J.P., Sarah, J.L. and Nicole, M. (1998) Histochemical and cytochemical investigations of phenols in roots of banana infected by burrowing nematode Radopholus similis. Phytopathology, 88, 1141-1148.

Wuyts, N., Swennen, R. and De Waele, D. (2006) Effects of plant phenylpropanoid pathway products and selected terpenoids and alkaloids on the behaviour of the plant-parasitic nematodes Radopholus similis, Pratylenchus penetrans and Meloidogyne incognita. Nematology, 8, 89-101.

Wuyts, N., Lognay, G., Verscheure, M., Marlier, M., De Waele, D. and Swennen, R. (2007) Potential physical and chemical barriers to infection by the burrowing nematode Radopholus similis in roots of susceptible and resistant banana (Musa spp.). Plant Pathology, 56, 878-890.

Yuan, S., Li, W., Li, Q., Wang, L., Cao, J. and Jiang, W. (2019) Defense responses, induced by $p$-coumaric acid and methyl $p$-coumarate, of jujube (Ziziphus jujuba Mill.) fruit against black spot rot caused by Alternaria alternata. Journal of Agricultural and Food Chemistry, 67, 2801-2810.

How to cite this article: Ewané CA, Nott K, Lassois L, et al. Severe modifications in source-sink ratio influence the susceptibility of bananas to crown rot and its phenolics content. Plant Pathol. 2020;00:1-14. https://doi.org/10.1111/ ppa.13243 